\title{
EFFECT OF JOB SATISFACTION AND PERCEPTION OF WORK OPPORTUNITIES TO TURNOVER INTENTION WITH ORGANIZATION COMMITMENT AS INTERVENING VARIABLES: THE CASE OF HOTELS IN EAST JAVA, INDONESIA
}

\author{
Fitria Lia*, Hariadi Bambang, Roekhudin \\ Faculty of Economics and Business, University of Brawijaya, Indonesia \\ *E-mail: liaa034@gmail.com
}

\begin{abstract}
This study aimed to examine the effect of job satisfaction and perceptions of job opportunities to the turnover intention and organizational commitment as an intervening variable. This study used the Theory of Reasoned Action, Two Factor Theory, Theory of Necessity, Theory of Planned Behavior and Theory of Motivation and Hope as the basis of this study. These studies use survey methods to collect data from selected samples. The chosen samples were managers who were placed at the middle management in 4-5 stars hospitality field institutions. There were 129 respondents total taken in this research. Nevertheless research trip to 5-star hotels do not provide research permit due to not accepting study from any party, therefore samples were taken from 4-star hotel in East Java for 71 respondents. This study uses Partial Least Square (PLS) in test data. Research result indicates that the job satisfaction has a positive influence on turnover intention, the perception of employment opportunities positive effect on turnover intention and positive effect on job satisfaction organizational commitment. But the perception of employment opportunities negatively affect organizational commitment, organizational commitment negatively affect turnover intention, not able to mediate organizational commitment to job satisfaction and turnover intention organizational commitment are not able to mediate the perception of job opportunities to turnover intention.
\end{abstract}

\section{KEY WORDS}

Job satisfaction, work opportunities perception, organizational commitment, turnover intention.

Turnover intention is one of the important factors that ought to be considered in achieving company goals. Turnover intention can be interpreted as employees' movement/intention in leaving the organization, whether, in the form of resignation or dismissal, high turnover intention also affects an organization's effectiveness due to the loss of experienced employees (Andini, 2006). According to Maertz and Campion (1998) in Samad (2006) identifying factors that influence turnover intention is an effective method for reducing real turnover. Research conducted by Bodla and Hameed, (2008) suggests that employee turnover impacts on high costs or social assets loss risk.

The phenomenon of turnover intention resulted in recruitment cost and sales force training losses. Turnover behavior can be predicted by using the variable intention (intention) stated in Theory Of Reasoned Action (TRA). Theory of Reasoned Action (TRA) explained that the amount of goodwill that is owned by someone will step up efforts to carry out an actual behavior. Ajzen and Fishbein (1980) stated that intention (intention) is the best predictor of actual behavior. Hence the importance of providing support, motivation, and contribution to an employee in improving high-performance productivity, so it does not cause an impact on turnover intention and erode the commitment within the organization. Organizational commitment received important attention to the study of organizational behavior (organizational behavior). There are several reasons regarding why organizational commitment is better compared to intervening variables in this study, which is described as follows: (1) because committed employees will produce better performance than those who are less committed (Jauch et al., 1978, Mowday et al., 1974), (2) because Organizational commitment is a better predictor of employee movement compared to job satisfaction (Porter 
et al., 1974), and (3) because organizational commitment can be used as a predictor of overall organizational success (Steers 1977).

Furthermore, one of the various factors that need to be paid attention by companies to reduce turnover intention level is to improve employee satisfaction so it does not impact on the perception of better job opportunities than previous placement. Some research on job satisfaction has consistently maintained that work mismatch will reduce job satisfaction, eroding the commitment to the organization, and there will be the perception of employment opportunities as well as leading to increased intention to resign or turnover intention (Lathifah 2008; Gieter Hofmans and Pepermans, 2011; Son and Wibawa, 2015). There's abundant work opportunity in the world, causing a higher employee tendency in leaving an organization. The large availability of job opportunities changes the attitudes of employees to their current employment status (Gerhart, 1990; Hulin et al., 1985).

Past research has associated with a high turnover intention empirically researched on some of them public accountant from research conducted Latifah (2008); Gieter, Hofmans, and Pepermans (2011); Handaru (2012); and of Putra dan Wibawa (2015) showed a significant effect of job satisfaction on turnover intention. This study replicated research and development by Putra and Wibawa (2015), entitled influence on turnover intention job satisfaction and organizational commitment as an intervening variable in PT. Autobagus Rent Car Bali. In contrast to the research of Putra and Wibawa (2015) in addition to different research objects, the researcher also added another variable from previous research which is also very influential in this research with the hope of getting a more accurate result by adding job opportunity perception variable in Rahman, Naqvi and Ramay (2008). as follows:

Based on research background described above, this research problem is formulated

1. Does job satisfaction influence on turnover intention of a manager in the hotels East Java?

2. Does the perception of employment opportunities influence the turnover intention of a manager in the hotels East Java?

3. Does job satisfaction affect the organizational commitment of a manager in the hotels East Java?

4. Does the perception of job opportunities affect on organizational commitment of a manager in the hotels East Java?

5. Does the organizational commitment influence on turnover intention of a manager in the hotels East Java?

6. Does job satisfaction influence on turnover intention through an intervening variable organizational commitment as a manager in the hotels East Java?

7. Does the perception of job opportunities effect on turnover intention through an intervening variable organizational commitment as a manager in the hotels East Java?

In accordance with the formulation of the above problems, this study has the following objectives:

1. To test the effect of job satisfaction on turnover intention of a manager in the hotels East Java.

2. To test the effect of the perception of job opportunities to the turnover intention of a manager in the hotels East Java.

3. To test the effect of job satisfaction on organizational commitment of a manager in the hotels East Java

4. To test the effect of the perception of job opportunities on organizational commitment of a manager in the hotels East Java

5. To test influence organizational commitment to the turnover intention of a manager in the hotels East Java.

6. To test the effect of job satisfaction on turnover intention through organizational commitment as an intervening variable of a manager in the hotels East Java. 
7. To test the effect of the perception of job opportunities to turnover intention through an intervening variable organizational commitment as a manager in the hotels East Java.

Research study would improve the literature in behavioral accounting for predicting turnover intention that can use the variable job satisfaction and perceptions of employment opportunities Thus, the two variables is exactly what contributes theory. Then the results showed that job satisfaction has a positive and significant impact on organizational commitment. Thus only job satisfaction variables that contribute to the application of the theory of Maslow's needs as well as the theory of two factors (two-factor theory). Furthermore, these findings may provide a practical contribution to Hotels in East Java to improve a better working atmosphere, increasing the manager's satisfaction with the factors described in this study. Improving manager perception or belief to remain in the company so that it does not impact on the high perception of job opportunities outside of the company resulting in increased turnover intention in the company.

\section{LITERATURE REVIEW AND HYPOTHESIS DEVELOPMENT}

Theory Of Reasoned Action (TRA). Theory of Reasoned Action developed by Fishiben and Ajzen (1980). Theory Of Reasoned Action (TRA) is correlated faith (belief), attitude (attitude), will (intention) and behavior (behavior). Theory of Reasoned Action (TRA) defines the attitude of a person is an effective component that has direct consequences for behavioral intentions (Ajzen and Fishbein, 1980: 5).

Two Factor Theory. There are several theories explaining job satisfaction. One of the most prevalent is the Two Factor Theory (Wexley and Yuki, 1977). Job satisfaction and job dissatisfaction are two different aspects. The difference between these two aspects in terms of satisfaction and dissatisfaction with work is not a consistent variable (Herzberg, 1966). Satisfiers also called motivators. Satisfiers are factors or circumstances that demonstrated job satisfaction source. These factors consist of: achievement, reward, promotion, responsibility, and work itself (Herzberg, 1966). While dissatisfier called Hygiene Factor which proved to be a source of dissatisfaction. These factors consist of salary, corporate policy, supervision, personal relationships, working conditions and occupations (Herzberg, 1966).

Needs Theory. Abraham Maslow in Malayu (2001: 152) describes the theory of motivation which is better known as the hierarchy of needs. These needs are often called Maslow as the basic needs described as a hierarchy or ladder depicting the level of need. According to Maslow, the satisfaction of various needs is driven by two forces i.e motivational deficiency (deficiency motivation) and motivational development (growth motivation). The deficiency motivation aims to overcome the problem of human tension due to various shortcomings. While the growth motivation is based on the capacity of every human being able to grow and develop.

Theory of Planned Behavior (TPB). Theory of Planned Behavior (TPB) which is the development of the Theory of Reasoned Action (TRA). Ajzen (1980) developed this theory by adding constructs not available yet in the TRA. This construct is called by the perceived behavior control (perceived behavioral control). This construct is added to the TPB to control individual behavior limited by its shortcomings and the limitations of the inadequate resources used to perform its behavior.

Motivation Theory and Hope Theory. Robbins (1998) defines motivation as a willingness to expend high levels of effort for organizational goals and is conditioned by the ability to meet individual needs. Motivation is an important concept for behavioral science because organizational effectiveness depends on the individual or employee effort to play the role the organization expects. Expectancy theory (Expectancy theory) is an individual work motivation to perform a task depends on the belief in the rewards received.

Effect of Job Satisfaction on Turnover Intention. There are two types of needs factors, namely the need for health and maintenance. This is related to the nature of human beings endeavor to obtain outward tranquility. Previous research focusing on the effect of job 
satisfaction on turnover intention is research conducted by Gieter, Hofmans, and Pepermans (2011); Handaru (2012); Nugroho (2012) and Putra and Wibawa (2015) exhibits a significant positive influence on job satisfaction on turnover intention. Based on the research mentioned that higher job satisfaction caused smaller intention to leave the company and vice versa, the lower the job satisfaction increased intention to leave the company.

$\mathrm{H} 1$ : Job satisfaction influence on turnover intention of a manager in East Java hotels.

Influence Perception of employment opportunities to turnover intention. Granting compensation (reward) should be tied to job performance (performance). Even if the compensation has been based on performance criteria. Should workers perceive low, it would cause lower job performance and increased turnover and absenteeism (Robbins, 2003). Previous research that focuses on variable perception of job opportunities to turnover intention is conducted by Rahman, Naqvy, and Ramay (2008); Dardar, Jusoh and Rasli (2012); Saeed and Shabir (2013; and Saleem and Gul (2013), which exhibits significant positive influence on perceptions of job opportunities to turnover intention. Based on the above research states higher employment opportunities cause higher turnover intention, and vice versa lower perceptions of job opportunities will cause low turnover intention.

$\mathrm{H} 2$ : Perception of employment opportunities influence the turnover intention of a manager in East Java hotels.

The Influence of Job Satisfaction on Organizational Commitment. Previous research focusing on job satisfaction on organizational commitment is research conducted by Andini (2006); Sijabat (2009); Parwita (2013); Iqbal, Ehsan and Rizwan (2014) and Rismawan (2014) and showed a positive influence on job satisfaction and organizational commitment. The higher the job satisfaction the higher organization employee commitment, the lower the job satisfaction causes lower organization employee commitment.

H3: Job satisfaction influence the organizational commitment of a manager in East Java hospitality field.

The Influence of Job Opportunity Perception on Organizational Commitment. How far the employee's commitment to the organization they work in is crucial to the organization in achieving its objectives. When an employee feels that the company does not provide the desired resources for an organization, then the response is to find another way to find another better job. The higher the level of perception of employee job opportunities, the lower the level of commitment of employees in the organization. Previous research focusing on job opportunity perceptions of organizational commitment is a study by Thatcher, Stephina, and Boyle (2003): Rahman, Naqvy, and Ramay (2008) and Mushtaq. Et al., (2014) indicating that there is a significant negative influence on the perception of employment opportunities on organizational commitment.

H4: Perceptions of job opportunities influence the organizational commitment of a manager in East Java hotels.

Influence of Organizational Commitment on Turnover Intention. Employee commitment to the organization causes them to be loyal to the organization and work well for the benefit of the organization (Yuwalliatin, 2006). Past research has focused on variables influence organizational commitment to turnover intention is that research conducted by Utami (2009); Handaru and Muna (2012) and Tnay et.al., (2013); which indicates that the presence of a significant positive effect between organizational commitment to turnover intention. Some of the above research describes employees who receive support from the employer through an assessment of their contribution to the organization, it will increase the support of the organization and eventually become low turnover intention.

$\mathrm{H}$ 5: Organizational commitment influence on turnover intention of a manager in East Java hotels.

Effect of Job Satisfaction and Perceptions of Work Opportunities Against Turnover Intention Through Organizational Commitment As an intervening variable. Turnover on Attitude Traditional Theory, this theory explains that in predicting the behavior of turnover on employees affected by job satisfaction and organizational commitment as intermediate variables (Zhao and Liu, 2010). Previous research focusing on research on organizational commitment variables as intervening variables is research conducted by Devi (2009); 
Suryani (2011); Rismawan (2014); Putra and Wibawa (2015) indicating that there is indirect influence between independent variables and dependent variables through intervening variable.

H6: Job satisfaction influence on turnover intention through an organizational commitment to the hotel managers in East Java.

H7: Perceptions of job opportunities effect on turnover intention through an organizational commitment to the hotel managers in East Java.

\section{METHODS OF RESEARCH}

Research design. This study uses explanatory research, which describes a relationship between variables through hypothesis testing (Ghozali, 2002). This research is used to test the hypothesis on the relationship (cause and effect) between existing variables. In explanatory research, the approach used is survey method.

Population and Sample. The population in this research was managers at the middle management positions in the hospitality field institution in East Java. Those managers are posted in 5-star hotel and 4-star hotel. The number of 5 stars and 4-star hotels in East Java which used as the population in this research is 31 (thirty-one) hotels spread in Java area east which is 12 (twelve) hotel from 5-star hotels and 19 (nineteen) hotel of a 4-star hotel. Sampling technique in this research is nonrandom using convenience sampling, samples selected are manager posted in middle management at hospitality field institution such as 5 and 4 in East Java. There was 129 respondents total.

Data Collection Techniques. Data were collected through questionnaires. The questionnaire was delivered directly to the 5 star and 4-star hotels where respondents worked. The data collection was conducted in 3 ways, direct delivery, transmitted through a computer connected to the Internet via e-mail to the department of human resources (HR) and delivered through a smartphone connected to the Internet.

Variables Operational Definition:

Job satisfaction. Job satisfaction is a general attitude of a person to his work in the form of feelings or positive assessment of the work resulting from an evaluation that has been done by someone. Job satisfaction measurement was adapted from research conducted by Watson, Thompson, and Meade (2007) and Pradana and Salehudin (2015).

Perception of Employment Opportunities. On occurrence when the employee feels that the company does not provide the desired resources for an organization, then the response is to seek for a better job. To measure perceptions of employment opportunities, the method was adapted from research conducted by (Mowdey et al., 1984).

Organizational Commitment. Organizational commitment is a psychological state characterized by employee relationships with organizations that affect employee loyalty to the organization (Allen and Meyer, 1993). To measure organizational commitment, the researcher used a method adapted from research conducted by Mowday et al. , (1979), Meyer et al., And Luthans (2006).

Turnover Intention. Turnover intention reflects a person's desire to seek other better employment alternatives (Mukhlish and Salehudin, 2008). To measure the turnover intention, the method was adapted from research conducted by Mobley (1977) and Price (1977).

Data Analysis Technique. Hypothesis testing is done by conducting Partial Least Square (PLS) model approach through Smartpls software version 2.0. PLS is an analysis of variance-based structural equations that can simultaneously perform testing of measurement models as well as testing structural models.

\section{RESULTS AND DISCUSSION}

\section{Research Object Description}

The distribution of questionnaires to 5-star hospitality field institution was not accepted because hospitality field parties had not received any research from any party except for an internship at the hotel for three months, therefore said questionnaires that did not return from 
5-star hotels amounted to 34 questionnaires. Then questionnaire of 4-star hospitality field that did not return was 24 questionnaires. The total number of questionnaires that did not return was 58, then 71 questionnaires were returned and can be used from 129 distributed questionnaires. The following table is the distribution of respondents of 4-star hotels.

Table 1 - Distribution of respondents

\begin{tabular}{lcc}
\hline \multicolumn{1}{c}{ Name Hotels } & Questionnaires & Back \\
\hline Hotel Santika premiere gubeng & Deployed & 5 \\
Hotel Aria Centra Surabaya & 5 & 5 \\
Rich Palace hotel & 5 & 5 \\
Garden palace hotel & 5 & 5 \\
Java paragon hotel residence & 5 & 3 \\
Savana Hotel \& Convention & 5 & 5 \\
Aria Gajayana Hotel & 5 & 5 \\
Hotel Santika Premiere Malang & 5 & 3 \\
Best Western OJ Hotel & 5 & 5 \\
Harris Hotel \& Conventions Malang & 5 \\
Surya Hotel \& Cottages Prigen & 5 & 3 \\
Grand Surya Hotel Kediri & 5 & 5 \\
Crown Victoria Hotel & 5 & 3 \\
Aston Jember Hotel \& Conference Center & 5 & 2 \\
Aston Madiun Hotel \& Conference center & 5 & 5 \\
Baobab Safari Resort & 5 & 3 \\
Tretes Raya Hotel \& Resort & 5 & 2 \\
Beejay Bakau Resort & 5 & 3 \\
ljen Resort \& Villas & 5 & 71 \\
\hline
\end{tabular}

Evaluation of Formative Model Construct Validity. Table 2 indicator Y.6 yields Tstatistics value less than T-table (1.96), thus declared invalid indicators to measure the variables turnover intention. While other indicators produce more T-statistics than T-table (1.96), thus declared valid indicator to measure the variables turnover intention.

Table 2 - Convergent Validity Results Formative Model

\begin{tabular}{|c|c|c|c|c|}
\hline Variable & Indicator & Original Sample (O) & T Statistics (|O/STERR|) & Information \\
\hline \multirow{4}{*}{ Turnover Intention } & Y.1 & 0.345 & 4.630 & Valid \\
\cline { 2 - 5 } & Y.2 & 0.150 & 2.014 & Valid \\
\cline { 2 - 5 } & Y.3 & 0.337 & 5.098 & Valid \\
\cline { 2 - 5 } & Y.4 & -0.302 & 5.357 & Valid \\
\cline { 2 - 5 } & Y.5 & 0.180 & 2.166 & Valid \\
\cline { 2 - 5 } & $Y .6$ & 0.062 & 0.871 & Invalid \\
\hline
\end{tabular}

Evaluation of Conflict Model Reflective Validity. Based on the table above, it exhibits that all indicators are worth greater than 0.5. Thus the indicator is declared valid to measure the variable.

Table 3 - Loading Factor Results

\begin{tabular}{|c|c|c|c|c|}
\hline Variable & Indicator & Original Sample (O) & T Statistics (|O/STERR|) & Information \\
\hline \multirow{4}{*}{ Job Satisfaction } & $\mathrm{X} 1.3$ & 0.799 & 35.430 & Valid \\
\cline { 2 - 5 } & $\mathrm{X} 1.4$ & 0.787 & 29.095 & Valid \\
\cline { 2 - 5 } & $\mathrm{X} 1.5$ & 0.854 & 48.891 & Valid \\
\cline { 2 - 5 } & $\mathrm{X} 1.6$ & 0.855 & 40.547 & Valid \\
\hline \multirow{3}{*}{$\begin{array}{c}\text { Perception of Employment } \\
\text { Opportunities }\end{array}$} & $\mathrm{X} 2.1$ & 0.927 & 111.461 & Valid \\
\cline { 2 - 5 } & $\mathrm{X} 2.2$ & 0.835 & 30.902 & Valid \\
\cline { 2 - 5 } & $\mathrm{X} 2.3$ & 0.912 & 70.232 & Valid \\
\hline \multirow{3}{*}{ Organizational Commitment } & $\mathrm{Z} .6$ & 0.788 & 34.055 & Valid \\
\cline { 2 - 5 } & $\mathrm{Z} .7$ & 0.809 & 38.461 & Valid \\
\cline { 2 - 5 } & $\mathrm{Z} .8$ & 0.882 & 60.917 & Valid \\
\cline { 2 - 5 } & $\mathrm{Z} .9$ & 0.874 & 43.414 & \\
\hline
\end{tabular}


Table 4 - Average Variance Extracted (AVE) and Communality Results

\begin{tabular}{|c|c|c|c|}
\hline Variable & AVE & Commonality & Information \\
\hline Job Satisfaction & 0.680 & 0.680 & Valid \\
\hline Perception of Employment Opportunities & 0.796 & 0.796 & Valid \\
\hline Organizational Commitment & 0.704 & 0.704 & Valid \\
\hline
\end{tabular}

Table 4 exhibits all variables generate value Average Variance Extracted (AVE) and Communality Which greater than 0.5 . Thus the indicator is declared valid to measure the variable.

Table 5 - Cross Correlation Results

\begin{tabular}{|c|c|c|c|}
\hline- & Job Satisfaction & Perception of Employment Opportunities & Organizational Commitment \\
\hline $\mathrm{X} 1.3$ & 0.799 & -0.055 & 0.760 \\
\hline $\mathrm{X} 1.4$ & 0.787 & -0.053 & 0.687 \\
\hline $\mathrm{X} 1.5$ & 0.854 & 0.103 & 0.818 \\
\hline $\mathrm{X} 1.6$ & 0.855 & 0.033 & 0.849 \\
\hline $\mathrm{X} 2.1$ & 0.034 & 0.927 & 0.039 \\
\hline $\mathrm{X} 2.2$ & 0.094 & 0.835 & 0.118 \\
\hline $\mathrm{X} 2.3$ & -0.076 & 0.912 & -0.088 \\
\hline Z.6 & 0.744 & -0.067 & 0.788 \\
\hline Z.7 & 0.771 & 0.038 & 0.809 \\
\hline Z.8 & 0.824 & 0.062 & 0.882 \\
\hline Z.9 & 0.836 & 0.014 & 0.874 \\
\hline
\end{tabular}

Table 5 exhibits that all indicators produce a larger loading factor compared to cross correlation in other variables. Thus it can be stated that the indicator is able to measure the latent variables corresponding to the indicator.

Hypothesis Testing Results and Discussion:

Table 6 - Direct Coefficient Results

\begin{tabular}{|c|c|c|c|c|c|}
\hline Exogenous Variables & Endogen Variables & $\begin{array}{c}\text { Direct } \\
\text { Coefficient }\end{array}$ & $\begin{array}{c}\text { Standard } \\
\text { Error }\end{array}$ & T Statistics & Decision \\
\hline Job satisfaction & Turnover Intention & -0.461 & 0.142 & 3.253 & $\begin{array}{c}\text { Be } \\
\text { accepted }\end{array}$ \\
\hline $\begin{array}{c}\text { Perception of Employment } \\
\text { Opportunities }\end{array}$ & Turnover Intention & 0.520 & 0.035 & 15,013 & $\begin{array}{c}\text { Be } \\
\text { accepted }\end{array}$ \\
\hline Job satisfaction & $\begin{array}{c}\text { Organizational } \\
\text { Commitment }\end{array}$ & 0.947 & 0.008 & 114.543 & $\begin{array}{c}\text { Be } \\
\text { accepted }\end{array}$ \\
\hline $\begin{array}{c}\text { Perception of Employment } \\
\text { Opportunities }\end{array}$ & $\begin{array}{c}\text { Organizational } \\
\text { Commitment }\end{array}$ & 0.005 & 0.010 & 0.488 & Rejected \\
\hline Organizational Commitment & Turnover Intention & -0.018 & 0.149 & 0.124 & Rejected \\
\hline
\end{tabular}

Hypothesis 1: Table 6 exhibits T statistics value relationship between job satisfaction and turnover intention amounted to 3,253. The test results exhibit T statistics>1.96. Thus the first hypothesis is accepted. The research study was supported by previous research results conducted by Gieter, Hofmans, and Pepermans (2011), Nayaputera (2011), Handaru (2012), Nugroho (2012), Putra and Wibawa (2015) that job satisfaction has a positive influence on turnover intention. The results also support the Two Factor Theory (theory of two factors) that satisfiers are job satisfaction source factors. These factors are achievements, awards, promotions, responsibilities, and the work itself (Herzberg, 1966).

Hypothesis 2: Table 6 exhibits that T statistics relationship between perceptions of job opportunities to turnover intention amounted to 15013 . The test results show that $T$ statistics> 1.96. Hence hypothesis 2 is accepted. Research study support previous research results conducted by Rahman, Naqvy and Ramay (2008), Dardar, Jusoh, and Rasli (2012), Saeed and Shabir (2013), and Saleem and Gul (2013) that the perception of employment opportunities impacted positively on turnover intention. The results also support the Theory 
of Planned Behavior (TPB) that control the behavior of individuals is limited by the perceived shortcomings and limitations of a shortage of resources used to perform the behavior.

Hypothesis 3: Table 6 exhibits that T statistics relationship between job satisfaction and organizational commitment amounted to 114 543. The test results show that $\mathrm{T}$ statistics> 1.96. Thus hypothesis 3 is accepted. Research study supports several previous research results conducted by Andini (2006), Sijabat (2009), Parwita (2013), Iqbal Ehsan and Rizwan (2014) and Rismawan (2014) that job satisfaction positively affects organizational commitment. The results also support the Two Factor Theory (theory of two factors) that satisfiers or gratification is a situation that is demonstrated as a source of job satisfaction. The higher the job satisfaction of employees, the higher employee commitment itself.

Hypothesis 4: Table 6 exhibits T statistics relationship between perceptions of job opportunities on organizational commitment is equal to 0488. The test results show that $\mathrm{T}$ statistics $<1.96$. Hence hypothesis 4 is rejected. Research study supports several previous research results conducted by Thatcher Stephina and Boyle (2003), Rahman Naqvy and Ramay (2008) and Mushtaq. Et al., (2014) that there is a negative influence on the perception of employment opportunities and organizational commitment. The lower the perception of employment opportunities the higher the organization's commitment among employees. According to Thatcher, Stephina, and Boyle (2003) by growing positive beliefs about work and attitudes toward superiors, managers can increase their sense of engagement with the company.

Hypothesis 5: Table 6 exhibits that T statistics relationship between organizational commitment to turnover intention is equal to 0.124 . The test results show that $T$ statistics $<1.96$. Thus hypothesis 5 is rejected. The results support some of the previous research conducted by Andini (2006) and Ramay Naqvy Rahman (2008), Sijabat (2009) and Widodo (2010) that their negative influence significantly between organizational commitment to turnover intention. The high competition in finding jobs, compared to the limited job opportunity. The high competition in finding jobs that are not supported by extensive employment makes a person with a low organizational commitment choose to stay in the organization and refuse to move.

Indirect Effect Result:

Table 7 - Indirect Effect Results

\begin{tabular}{|c|c|c|c|c|c|}
\hline Exogenous Variables & $\begin{array}{c}\text { Endogen } \\
\text { Variables }\end{array}$ & $\begin{array}{c}\text { Intervening } \\
\text { Variables }\end{array}$ & $\begin{array}{c}\text { Indirect } \\
\text { Coefficient }\end{array}$ & $\begin{array}{c}\text { Standard Error } \\
\text { (STERR) }\end{array}$ & $\begin{array}{c}\text { T Statistics } \\
(\mid \text { O / STERR } \mid)\end{array}$ \\
\hline Job satisfaction & $\begin{array}{c}\text { Turnover } \\
\text { Intention }\end{array}$ & $\begin{array}{c}\text { Organizational } \\
\text { Commitment }\end{array}$ & -0.017 & 0.141 & -0.124 \\
\hline $\begin{array}{c}\text { Perception of } \\
\text { Employment } \\
\text { Opportunities }\end{array}$ & $\begin{array}{c}\text { Turnover } \\
\text { Intention }\end{array}$ & $\begin{array}{c}\text { Organizational } \\
\text { Commitment }\end{array}$ & 0.000 & 0.001 & -0.120 \\
\hline
\end{tabular}

Table 7 exhibits that the effect of job satisfaction on organizational commitment turnover intention through $T$ statistics obtained a value of -0124 . The test results show that $T$ statistics $<1.96$. Therefore, organizational commitment otherwise unable to mediate the effect of job satisfaction on the on turnover intention. Based on the research results are not in line with research conducted by Devi (2009), Rismawan (2014) and Putra dan Wibawa (2015). But this study is consistent with research conducted by Pareke, (2004) that there is no mediating role of job satisfaction on turnover intention and organizational commitment as an intermediary variable. Job satisfaction felt by an employee is not directly linked to the costs of financial losses that might he suffered while on the other hand connoted the organization's commitment to financial losses (Dunham et al., 1994).

Then influence the perception of job opportunities to turnover intention through organizational commitment $T$ statistics obtained a value of -0120 . The test results showed that $T$ statistics $<1.96$. Therefore, organizational commitment otherwise unable to mediate employment opportunities to influence the perception of the turnover intention. Based on the research results are not in line with research conducted by Suryani, (2011). But this study is consistent with research conducted by Thatcher, Stephina, and Boyle (2003), which showed 
that the alternatives job opportunities showed a negative correlation with organizational commitment. And alternative job opportunities showed a positive association with the intention of moving.

\section{CONCLUSION}

The findings of this study indicatesjob satisfaction has a positive influence on turnover intention. The study also found that the nature of jobs and promotions is an important factor in job satisfaction as a manager. The study's findings also indicate that the perception of job opportunities has a positive effect on turnover intention. The higher the perception of employment opportunities, the higher the turnover intention of a manager. The Research study indicate that job satisfaction has a positive influence on organizational commitment. The higher the job satisfaction of a manager, the higher the organizational commitment.

Perception of employment opportunities negatively affects organizational commitment a manager. A positive belief able to make the perception of job opportunities outside of the hospitality field field is not unthinkable in itself a manager but rather increase the commitment and motivation in them to always engage and persist in the company where he worked. Research result also exhibited that organizational commitment negatively affects turnover intention of a manager. The Research result also exhibits both job satisfaction and perceptions of employment opportunities negatively affect turnover intention through organizational commitment. This means that organizational commitment is not able to mediate the perception of job satisfaction and job opportunities to the turnover intention of a manager in 4 Stars hotel in East Java.

This study was unable to use simple random sampling (simple random sampling), but convenience sampling was applied. This study received permission to conduct research in the 5 stars hotel because said hospitality institution does not permit research from any party except those who participated in internships for at least three months. Only 4-stars hotel managers were included in the study population. Construct indicators of job satisfaction and organizational commitment each only four indicators for the construct validity of test current models of reflective, four indicators of job satisfaction variables and the five indicators of organizational commitment is removed to obtain better results.

This study could not explain all the factors that may affect turnover intention of a manager in East Java 4 starts hotel. Thus future research is expected to examine other factors beyond the variables used in this study or add the number of variables to complete the research models that predict turnover intention of a manager in the hospitality field, especially in 4 stars hotel East Java such as variable work load excess and work stress.

The implication of this research is aimed at practitioners, namely the owners and managers in 4 stars hotels hospitality institutions to better understand factors causing high turnover intention among managers. This research also provides implications for research, such as methods to minimize turnover intention among managers. Good governance system in hospitality can maintain the managers. They would continue to work in the Hospitality field and lower levels of turnover intention manager or look for another job opportunity.

\section{REFERENCES}

1. Ajzen, I., and Fishbein, M. 1980. Understanding Attitudes and Predicting Social Behavior. Prentice-Hall.

2. Allen, NJ and JP Meyer. 1991. The Measurement and antecedents of Affective, Continuance and Normative Commitment to the Organizational. Journal of Occupational Psychology. 63 (1): 1-18.

3. Andini, R., 2006. Influence Analysis Salary Satisfaction, Job Satisfaction, Commitment Organizational against Turnover Intention: A Case Study Roemani Muhammadiyah Hospital Semarang. Unpublished Graduate Thesis. University of Diponegoro. 
4. Bodla, MA and A. Hameed, 2008. Controllable vs. Uncontrollable Factors of Employee Turnover Intentions, An Empirical Evidence from Textile sector of Pakistan. Proceedings of the International conference on Business and Management at Bangkok.

5. Dardar, AHA Jusoh, A. Rasli, A. 2012. The impact of job training, job satisfaction and alternative job opportunities on job turnover in Libyan oil companie. Procedia - Social and Behavioral Sciences 40 (2012) 389 - 394.

6. Devi, EKD, 2009. Analysis of the influence of job satisfaction and motivation on employee performance with organizational commitment as an intervening variable (A Study on Employee Outsourcing PT. Semeru Karya Buana Semarang). Unpublished Graduate Thesis, Master of Management, Graduate School of Economics, University of Diponegoro.

7. Dunham, RB, Grube, JA, \& Castaneda, MB. 1994. Organizational commitment: the utility of an integrative definition. Journal of Applied Psychology, 79 (3): 370-380.

8. Gerhart, B. 1990. Voluntary turnover and alternative job opportunities. Journal of Applied Psychology, 75 (5), 467-476.

9. Ghozali, Imam. 2002. Applications Multivariate with SPSS. Semarang: Agency Publisher University of Diponegoro.

10. Gieter, D., S., Hofmans, J., and Pepermans, R. 2011. Revisiting the impact of job satisfaction and organizational commitment on turnover intention nurse: An individual differences analysis. International Journal of Nursing Studies 48 (2011) 1562- 1569.

11. Handaru, W.A. 2012. Effect of Salary Satisfaction and Organizational Commitment on Turnover Intention In Division PT. Social Security. Journal of Management Science Research Indonesia, Vol 3 No. 1.

12. Herzberg, F., Mausner, B., and Snyderman, BB 1959. The motivation to work. New York, NY: John Wiley \& Sons.

13. Hulin, CL, Roznowski, M., and Hachiya, D. 1985. Alternative opportunities and withdrawal decisions: Empirical and theoretical discrepancies and an integration. Psychological Bulletin, 97 (2), 233 -250.

14. Iqbal, S. Ehsan, S. and Rizwan, M. 2014. The impact of organizational commitment, job satisfaction, job stress and leadership support on turnover intention in educational institute. International Journal of Human Resource Studies ISSN 2162-3058 2014, Vol. 4, No. 2.

15. Jauch, LR, Glueck, WF, and Osborn RN 1978. Organizational Loyalty, Professional Commitment and Academic Research Productivity. Academy of Management Journal. March. Pp. 84-92.

16. Lathifah, I. 2008. Effects of Work-Family Conflict Against Trunover Intentions With Job satisfaction as an intervening variable. Empirical Study on the Public Accountant Auditor in Indonesia. Unpublished Graduate Thesis. Universitas Diponegoro.

17. Luthans, F, 2006. Organizational Behavior (Tenth Edition). Yogyakarta: Andi Offset.

18. Mobley, WH 1977. Intermediate Linkages in The Relationship between Job Satisfaction and Employee Turnover. Journal of Applied Psychology . 62: 237-240.

19. Mowday, RT, Koberg, CS, and McArthur, AW 1984. The psychology of the withdrawal process: A cross-validational test of Mobley's intermediate linkages models of turnover in two samples. Academy of Management Journal, 79-94.

20. Mowday, RT, RM Steers and Porter IW, 1979. The Measurement of Organizational Commitment. Journal of Applied Psychology, 84, p. 408-414.

21. Mowday, RT, Porter, LW and Dubin, R. 1974. Unit Performance, Situational Factor, and Employee Work Attitudes in spatially Separated Units. Organizational Behavior and Human Performance. October. Pp. 231-248.

22. Mukhlish, B., and Salehudin, I., 2008. Application of planned behavior framework in understanding the Influencing factors intention to leave among alumnae of the faculty of economics University of Indonesia Year 2000-2003. Proceedings of the 3rd International Conference on Business and Management Research. 3 (1), 99-106.

23. Nayaputra, Y. 2011. Analysis of Effect of Job Satisfaction and Job Stress on Customer Servise Employee Turnover Intention in PT. Plaza Indonesia Realty Tbk. Unpublished 
Graduate Thesis, Master Program Administration, Graduate Faculty of Social and Political Sciences, University of Indonesia.

24. Nugroho, AK, 2012. The effect of job insecurity, organizational commitment and job satisfaction of the desire out studies on Pera w at R S. PKU Muhammadiyah Surakarta. Unpublished Graduate Thesis, Master of Accounting Program, Faculty of Economics, University of Surakarta.

25. Pareke, J.F. 2004. Relations with the Justice and Satisfaction Desire Switching: The Role of Organizational Commitment As Pemediasi variables. JSB No. 9 Vol. 2 DECEMBER 2004157.

26. Parwita, GBS 2013. Effect of Job Satisfaction and Organizational Commitment Against Work Discipline Lecturer University Foundation Mahasaraswati In Denpasar. Unpublished Graduate Thesis, Master of Management, Graduate School of Economics, University of Udayana.

27. Porter, LW, Mowday, RT and Boulian, PV 1974. Organizational Commitment, Job Satisfaction and Turnover Among Psychiatric Technicians. Journal of Applied Psychology. October, pp. 603-609.

28. Pradana, A., and Salehudin, I. 2015. Work Overload and Turnover Intention of Junior Auditors In Greater Jakarta, Indonesia. The South East Asian Journal of Management, 9 (2), 108-124.

29. Price, JL 1977. The Study of Turnover. IA: lowa State University Press, Ames.

30. Son, M. and Authority, A. 2015. Influence of Job Satisfaction on Turnover Intention with Organizational Commitment As an intervening variable. E-Journal of Management Udayana University, Vol. 4, No. 4, 2015: 1100-1118.

31. Rahman, ASMM, Naqvi, R. and Ramay, IM 2008. Measuring Turnover Intention: A Study of IT Professionals in Pakistan. International Review of Business Research Papers Vol. 4 3 June 2008 Pp.45-55.

32. Rismawan, P. 2014. Role of Organizational Commitment Mediating Effects of Stress At work and Job Satisfaction Employee Out Of Intention. Udayana University Graduate Program.

33. Robbins, SP 1998. Organizational Behavior: Concepts, Controversies, Applications (8th ed). Upper Sadlle River, NJ: Prentice-Hall.

34. Robbins, SP. 2003. Organizational Behavior (Tenth Edition). Prentice-Hall, Jakarta.

35. Saeed, MM and Shabir, S. 2013. The impact of training and development on employees'skils enhancement and their subsequent intention to quit: the moderating role of perceived alternative job opportunities. ISSN 1993-8233. Academic Journals. Vol 7 (13), pp. 1030-1034, April 7, 2013.

36. Saleem, T. and Gul, S. 2012. Drivers of turnover intention in public sector organizatios: pay satisfaction, organizational commitment and employment opportunities. Middle-East Journal of Scientific Research 17 (6): 697-704, 2013. ISSN 1990-9233.

37. Samad, S. 2006. Predicting Turnover Intentions: The Case of Malaysian Government Doctors. The Journal of American Academy of Business, Cambridge, Vol.8, No.2, March.

38. Sijabat, J. 2009. Organizational Commitment Auditor At Large Firm in Jakarta, which is affiliated with the Foreign KAP (The Big Four). Accounting Studies, August 2009, p. 165177, ISSN: 1979-4886.

39. Steers, RM 1977. antecedents and Outcomes of Organizational Commitment. Administrative Science Quarterly. March. Pp. 46-56.

40. Suryai, R. 2011. Analysis of the influence the perception of organizational support to trnover intentions with the role of organizational commitment as mediation case study on PT. Mining. Unpublished Graduate Thesis, Master Program Administration, Graduate Faculty of Social and Political Sciences, University of Indonesia.

41. Thatcher, JB, Stepnia, LP and Boyle RJ 2003. Turnover of Information Technology Workers: Examining the Influence of Attitudes empirically, Job Characteristics and External Markets. Journal of Management Information Systems, Vol. 19, No. 3, pp. 231261. 
42. Tnay, E., Othman, A.E.A., Siong, H.C., Lim, S.L.O. 2013. The Influences of Job Satisfaction and Organizational Commitment on Turnover Intention. Procedia - Social and Behavioral Sciences 97 (2013) 201-208.

43. Utami, I., and Bonussyeani, S., E., N. 2009. Effect of Job Insecurity, Job Satisfaction and Organizational Commitment Against Switching Desire Job. Journals Accounting and Finance Indonesia, Volume 6 - Number 1, June 2009.

44. Watson, AM, Thompson, LF, and Meade, AW 2007. Measurement invariance of the job satisfaction survey work across Contexts. Proceedings of the 22nd Annual Meeting of the Society for Industrial and Organizational Psychology, New York.

45. Wexley, KN, and Yukl, G. 1977. Organization Behavior \& Personal Psychology. Illinois: Homewood.

46. Yuwalliatin, S, 2006. Influence of Organizational Culture, Motivation and Commitment And Its Effect on Performance of Competitive Advantage doses Unissula Semarang. Journal of Economics and Business, Vol. 7 No. 2, p. 241-256.

47. Zhao, Erdong and Liwei Liu. 2010. Comment Of Development of job embeddedness About Study To Turnover and ExplorationInto Application in Enterprises. Asian Social Science. 6 (6): pp: 63-64. 